\title{
The treatment of peritoneal carcinomatosis in elderly patients
}

\author{
A Macri $^{1 *}$, E Saladino ${ }^{1}$, V Adamo ${ }^{2}$, G Altavilla ${ }^{2}, G$ Condemi $^{3}$, E Mondello $^{4}$, A Sinardi ${ }^{4}, S$ Irato $^{5}$, C Famulari $^{1}$ \\ From de Senectute: Age and Health Forum \\ Catanzaro, Italy. 5-7 December 2009
}

\section{Background}

Peritoneal carcinomatosis is a frequent evolution of gastrointestinal and gynecologic malignancy and it has been regarded as a lethal clinical entity. Treatment options for these patients have improved significantly in the past few years. CytoReductive Surgery (CRS) plus Hyperthermic IntraPEritoneal Chemotherapy (HIPEC) is an aggressive and promising treatment for patients with peritoneal malignancies. Whether this type of major cancer surgery is feasible in elderly patients is an ongoing question.

\section{Materials and methods}

For this study we have only considered the patients with a minimal follow up of 18 months. For this reason we have evaluated 30 patients, $11(36,6 \%)$ aged $>65$ years, submitted, in the period May 2004 -April 2008, to 33 CRS plus HIPEC. Criteria of patients' eligibility were peritoneal carcinomatosis of different origins, T3-4 gastric cancer, ECOG performance status $\leq 2$, no extraabdominal extension and no evidence of bowel obstruction. For the intraoperative staging we have used the "Peritoneal Cancer Index" (PCI) [1] and to evaluate the entity of cytoreduction the "Completeness of Cytoreduction score" (CC score) [2] (Figure 1).

\section{Results}

Results of our experience are reported in Table 1.

\section{Conclusions}

The rationale of CRS plus HIPEC is based respectively on the removal of gross disease and on the eradication of microscopic residual disease. The peritoneal-plasma barrier retards the clearance of high molecular weight chemotherapy from the peritoneal cavity and allows a large exposure of small residual cancer nodules. Tissue

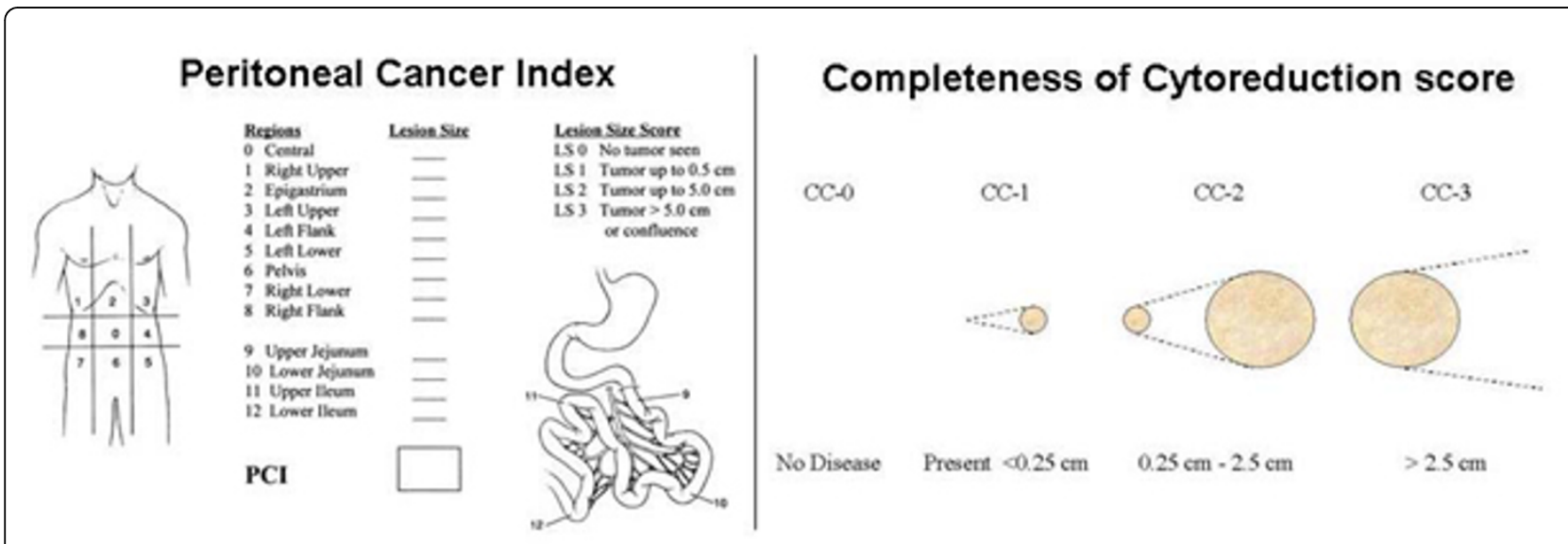

Figure 1 Peritoneal Cancer Index and Completeness of Cytoreduction score

${ }^{1}$ University of Messina, General Surgery Unit, Messina, Italy 
Table 1 characteristics of patients and results

\begin{tabular}{|c|c|c|c|c|c|c|c|c|c|c|c|}
\hline & Pts & Procedures & $\begin{array}{c}\text { Mean } \\
\text { age } \\
\text { (range) }\end{array}$ & $\begin{array}{c}\text { Chronic } \\
\text { comorbidities }\end{array}$ & $\begin{array}{l}\text { Mean duration } \\
\text { of surgery } \\
\text { (min.) }\end{array}$ & $\begin{array}{c}\text { Mean } \\
\text { PCI }\end{array}$ & CC score & $\begin{array}{l}\text { Mean postop. } \\
\text { hospital stay } \\
\text { (days) }\end{array}$ & Morbidity & Mortality & $\begin{array}{c}18 \text { mths } \\
\text { overall } \\
\text { surv. }\end{array}$ \\
\hline Total & 30 & 33 & $\begin{array}{c}58,3 \\
(30-77)\end{array}$ & $18 / 30(60 \%)$ & 556,7 & 8,2 & $\begin{array}{c}29 \text { pts: } 0 \\
\text { 3pts:1 } \\
1 \text { pt. } \\
\text { with } \\
\text { relapse: } 2\end{array}$ & 17 & $21,2 \%$ & $9 \%$ & $66,6 \%$ \\
\hline $\begin{array}{l}\text { Pts aged } \\
<65 \\
\text { years }\end{array}$ & 19 & 22 & $\begin{array}{c}52,7 \\
(30-63)\end{array}$ & $7 / 19(36,8 \%)$ & 551,3 & 8,1 & $\begin{array}{c}19 \text { pts: } 0 \\
2 \text { pts: } 1 \\
1 \text { pt. } \\
\text { with } \\
\text { relapse: } 2\end{array}$ & 17,2 & $18,1 \%$ & $4,5 \%$ & $68,4 \%$ \\
\hline $\begin{array}{l}\text { Pts aged } \\
>65 \\
\text { years }\end{array}$ & 11 & 11 & $\begin{array}{c}69,7 \\
(66-77)\end{array}$ & $11 / 11(100 \%)$ & 567,5 & 8,2 & $\begin{array}{l}10 \text { pts: } 0 \\
1 \text { pt: } 1\end{array}$ & 15,6 & $27,2 \%$ & $18,1 \%$ & $63,6 \%$ \\
\hline
\end{tabular}

penetration of the intraperitoneal chemotherapy is facilitated by moderate hyperthermia $\left(41-42^{\circ} \mathrm{C}\right)$. This promising therapeutic approach is associated with significant morbidity and mortality and the surgical risk in elderly patients is even higher, since these people suffer from frequent comorbidities [3]. In our experience we have recorded, in elderly patients, higher, but acceptable, morbidity $(27,2 \%$ vs $18,1 \%)$ and mortality $(18,1 \%$ vs $4,5 \%)$, probably correlated with their comorbidities (100\% vs $36,8 \%)$, lower mean postoperative hospital stay $(15,6$ days vs 17,2$)$ and a good 18 -months overall survival $(63,6 \%)$. We retain, on the basis of our experience and of the data of the literature [3], that age and advanced peritoneal malignancy should not preclude patients from the maximal surgical effort.

\section{Author details}

${ }^{1}$ University of Messina, General Surgery Unit, Messina, Italy. ${ }^{2}$ University of Messina, Medical Oncology Unit,Messina, Italy. ${ }^{3}$ Ospedali Riuniti della Locride, Hospital of Siderno, Medical Oncology Unit, Siderno, Italy. ${ }^{4}$ University of Messina, Anesthesiology Unit, Messina, Italy. ${ }^{5}$ University of Messina, Gynecologic Oncology Unit, Messina, Italy.

Published: 19 May 2010

\section{References}

1. Quantitative methodologies for selection of patients with recurrent abdominopelvic sarcoma for treatment.. Berthet B, Sugarbaker TA, Chang D, Sugarbaker PH: Eur J Cancer 1999, 35(3):413-9.

2. Sugarbaker $\mathrm{PH}$ : Current Indications for Cytoreductive Surgery and Intraperitoneal Chemotherapy. Management of peritoneal surface malignancy using intraperitoneal chemotherapy and cytoreductive surgery. The Ludann Company Grand Rapids eds., Michigan. 1998, 18.

3. Mueller $\mathrm{H}$, Hahn M, Simsa J: Cytoreductive surgery in the elderly patients-is it feasible? Hepatogastroenterology 2008, 55(88):2005-11.

\section{Submit your next manuscript to BioMed Central} and take full advantage of:

- Convenient online submission

- Thorough peer review

- No space constraints or color figure charges

- Immediate publication on acceptance

- Inclusion in PubMed, CAS, Scopus and Google Scholar

- Research which is freely available for redistribution

Submit your manuscript at www.biomedcentral.com/submit 